\title{
Radical Reference: Socially Responsible Librarianship Collaborating With Community
}

\author{
Melissa Morrone \& Lia Friedman
}

Morrone, Melissa and Lia Friedman. 2009. Radical Reference: Socially responsible librarianship collaborating with community. The Reference Librarian 50, no. 4: 371-396. DOI: $10.1080 / 02763870903267952$ dx.doi.org/10.1080/02763870903267952

\section{Abstract:}

To date, the written record of socially responsible librarianship chiefly concerns outreach to previously-disregarded constituencies and the relationship between library collections and the alternative press. Although librarians and activists have long shared a history, descriptions of their collaborations are scarce, and there is little to no documentation of the provision of reference and information literacy services in the context of socially responsible library work. In this article, we discuss the history of Radical Reference (RR), a collective of progressive library workers and students. We consider RR's evolution from a "street" and online reference collective to one that provides a variety of socially conscious information services. We also explore examples of RR members' forming extra-institutional bonds with activists and independent journalists.

Previous versions of this paper have appeared in various journals, including the IFLA Journal.

\section{Introduction and Background}

Information-seeking processes in librarianship are rapidly changing. Whether in public, university or private institutions, library workers are in a state of constant adjustment to new technologies and techniques for finding relevant, useful information. In this environment, librarians must make contact with their targeted base and serve them in the manner best suited to the situation. Moreover, there are those who may have varying comfort levels with these shifting and growing technologies, so it is equally important to be cognizant of who has easy access to information, computers and online resources and has been taught to use them, as well as who has not.

Radical Reference (RR) is a collective of progressive library workers and students who use virtual and face-to-face reference services to reach out to members of an identified 
community base. Among the "defining characteristics and intent of progressive librarianship" that Toni Samek articulates, RR fits with many. RR rejects a "neutral" stance and the commercialization of data and information, works towards equality of access to information services, "[c]onsiders the librarian as citizen as well as the librarian as professional," and "[e]mploys community coalitions and alliances between progressive librarians and with other like-minded groups" (Samek 2004).

RR defines its targeted patron base as progressive activists and independent journalists. Unlike in a traditional library/patron model, the relationship between these communities and information services does not necessarily fall within the traditional brick and mortar library setting. Most of these people are no longer-if ever they wereenrolled in universities and thus lack access to extensive book collections and subscription databases. At the same time, many do not take advantage of public libraries and their staff; reasons include the belief (founded or not) that those collections do not contain the sorts of literature and resources they need for their work and the perception (shared, of course, with members of the general public) that librarians do not offer much more expertise than that which can be acquired by spending some time on Google.

\section{Evolving Reference Services}

At the inception of RR in July of 2004, founders defined its service base as political activists and independent journalists who were converging to protest the 2004 Republican National Convention (RNC) in New York City. These volunteer librarians recognized a need for information services that would be available to all and accessible not just at a reference desk, but also in the streets, cafes, and parks where activists gathered. These street reference volunteers were armed with "ready reference kits" specific to the RNC, including maps and lists of demonstrations and official events, and connected via cell phone to home support librarians who extended available information resources and provided synchronous communication. Activist events like protests are fluid and shifting, as are the information needs of their participants. These tend to range from the practical ("if I am riding my bike and am arrested, what are my rights?") to the broad ("What are these people protesting about?") to the mundane and familiar ("Where is the closest restroom?"). In turn, the response had to be equally heterogeneous.

An alternate method used for gathering and disseminating information during the RNC was through a synchronous Web-based messaging service, the now-defunct TXTmob. TXTmob "[let] you quickly ... share text messages with friends, comrades, and total strangers [with a] format ... similar to an email b[ulletin]-board system" (http://www.txtmob.com). Messages could be sent simultaneously to multiple groups that needed access to the same information at the same time. TXTmob was developed by the Institute for Applied Autonomy to support activists at the Democratic and Republican National Conventions in 2004. The service allowed real-time reference help as well as information on peripheral yet equally important updates, such as: "the police have cordoned off 7th street and are arresting everyone they encounter." With the advent of new technologies come new possibilities in street reference. The presence of 
services that provide synchronous connectivity like Skype, a Web-based phone, text and video service; the recent use of Twitter during the bombings in Mumbai (Lamb 2009); and the ever popular iPhone with applications like Google Latitude and Loopt indicate that new methods of connecting continue to appear on the horizon.

Because RR was created to support activism and connect users with quality information regardless of their ability to locate trusted data on their own or access a physical library space, street protests were a logical place to meet the users at their point of need. The project was well-received by the activist community in 2004 and has since continued and expanded to include resources such as Web research guides and workshops conducted throughout the United States. Currently RR's most prominent service is an online reference forum, where questions are archived, creating a knowledge base accessible to site visitors and online searchers. The website also features a "reference shelf" of subject guides that cover topics from alternative bookstores and infoshops (community hubs of activist fliers, pamphlets and books), to history and resistance, to a comprehensive pathfinder for "green scare" resources.

\section{Radical Reference Online}

The knowledge base created by questions and answers provides RR's most dynamic resource and forms the bulk of the website's content. The spirit of collaboration that RR saw with street reference is also present here. Many questions are answered with the aid of internal notes (viewable only by authenticated members), allowing a virtual conversation among librarians. RR members have different areas of expertise and interest, and there is an attempt to use many minds to put together a quality answer. As of January 2009, RR had over 300 subscribers to its member email list-library workers with a variety of professional backgrounds and the ability to answer queries in nine languages.

As represented on the site, RR believes that the use of particular technologies represents an ideological decision rather than a neutral operation and that proprietary software stands in the way of the need for autonomous solutions. While staff at libraries that use Microsoft Windows software-by far the most common operating system-may believe that they're making unbiased technology decisions, others who use open source or free software are aware of the political implications and strive to use open source solutions. Free/libre open source software (FLOSS) is best described as being free as in speech, not as in lunch. In other words, lack of cost alone does not make something "free"; rather, it is the philosophy of openness and liberty behind the software that counts. The generally agreed-upon criteria of FLOSS, as stated by the Free Software Foundation, are that one is free to: Run a program for any purpose. Study the program and make changes as desired. Redistribute copies. Improve the program and release modified versions to the community (Free Software Foundation 2009).

\section{Neutrality and Information Literacy}


The connected issues of neutrality and intellectual freedom are central to a discussion of social responsibilities in librarianship. The goal of RR's reference service is to answer questions to the best of one's ability as a trained librarian and supply the public with search strategies and skills for finding valuable information on their own. As activists with social justice values, RR members understand there is a pantheon of underrated alternative resources-books, websites, databases, and more-that are ignored in mainstream culture. However, while RR operates from a Left perspective, it is not RR's intent to promote left-wing sources over traditional resources. The best tools and strategies available are used to answer a question as thoroughly as possible, and the question of who is reporting on a topic, where information is being published, or how data are gathered and distributed cannot always be neatly divided into sources that are socially responsible and those that are not.

RR members take their skills and values in evaluating resources and bring them to the social justice communities of which they are part. When doing outreach to activist communities, traditional library services are not avoided. For example, at a Really Really Free Market in Manhattan where one of the authors had set up a RR station, a woman inquired about opening her own daycare. Each of the three library systems in New York City provides specialized business information services, and the Brooklyn Public Library has an online guide to resources about operating a daycare, so those were the referrals given. "Neutrality can obfuscate injustices and the possibilities for active contributions. Often, neutrality is not a defense of the controversial, but rather an avoidance of it .... In its broadest and most vital sense, intellectual freedom means the active promotion and protection of equal access to information as an inalienable right of all citizens" (Schuman 1987, 131).

The answers to questions on the RR website are often conversational in tone while aiming to be thorough and of a high quality. This balance between formal and informal is intended to demystify the current information environment and empower the questioner to interpret and expand on the results as best fits his or her need. Generally, the answerer avoids injecting personal analysis (except as suits the question) but consistently maps the methodology undertaken to arrive at the answer. RR members encourage askers to seek out additional sources, including those located in public libraries in the patron's own area, along with intelligent use of the open Web. While some RR patrons may prefer a simpler answer without the search strategy or list of sources articulated, the librarians believe the process of finding and interpreting information is as important as the answer to the question itself.

Challenges to the organization will be familiar to anyone who has been part of an allvolunteer effort. Members come and go; there are issues with providing answers in a timely manner, and administrators may pull back from daily duties given the constraints of work, school or family life. There is a constant need to be active and present in social justice communities as library workers and maintain the connection to RR. That said, the community is strong and evolving, with people ready to step up when others step back. The fluidity that comes into play when members are allowed to do the work that they can, when they can, allows for a freedom and strength that makes this library 
community vital. Key to retention and a robust organization is the need to stay enthusiastic and invested, and to encourage other members to feel the same.

Like all volunteer-based projects, $R R$ experiences both the good and the bad of being composed of people committing to tasks in their spare time. Luckily, people bring energy and ideas because they want to, not because they are being paid to. Some librarians who cannot fully incorporate their values into their paid work come to volunteer for RR for that fulfillment, as RR is a space where questions are asked by people who share a commitment to social justice.

RR subscribes to no one political philosophy, and the allegiances of individual members likely range from liberal Democrat to anarchist. Although RR rejects a traditional hierarchical business model, there is a small core group of administrators who monitor the site, provide help to new members, and coordinate ongoing projects. RR also does not believe that an MLS is a line in the sand demarcating who has authority to disseminate and procure information and who does not. Many members of RR are degreed librarians, but active members include students, library support staff, and librarians of life as well.

The Subcommittee on Social Responsibilities of the American Library Association (ALA) issued a report in January 1970 arguing that "if libraries exist to promote the progress of meaningful democracy, then the apparently nonlibrary problems of the disadvantaged, and more acutely the problems that cause disadvantage, are library problems. They have an information component. Libraries have a role to play in helping communities reach 'a state of political effectiveness where they can demand proper, self-tailored library services and be sure of getting it'" (Raber 2007, 684-5). The members of RR equally subscribe to this view and are putting energy towards resolving the "information component" of the disconnectedness of activists and independent journalists. While we

may also work for a more socially responsible librarianship at our places of employment, $\mathrm{RR}$ is the space for us to bring librarian expertise outside of our institutions and into our communities.

\section{Radical Reference in Context: Socially Responsible Librarianship}

Radical Reference is one in a long line of socially responsible projects in librarianship. This section covers the heightening awareness of social responsibilities in the field in the 1960s and '70s, the growing emphasis on outreach in library work, librarians and the alternative press, and the significance of connections to outside organizations.

The documented story of a social conscience in the library profession begins largely within the American Library Association (ALA). As has been recorded by Samek and others, "[i]ncreased ALA responsiveness to its membership was a central issue for activist librarians in the 1930s and again in the 1960s" (Samek 2004). For detailed descriptions and analysis of the upheaval librarianship experienced through ALA during the second wave of library activism, Toni Samek's Intellectual Freedom and Social Responsibility in American Librarianship, 1967-1974 (Samek 2001) and Douglas 
Raber's "ACONDA and ANACONDA: Social Change, Social Responsibility, and Librarianship" (Raber 2007) are two thorough sources.

The written record of socially responsible librarianship thus far has generally concerned two elements: outreach to previously-disregarded constituencies, and inclusion and support of the alternative press. Furthermore, most documentation on the history of library activism concerns action within professional associations, particularly ALA. Groups such as Librarians for Peace (which marched against the war in Vietnam) and Librarians for Nuclear Arms Control (which was active in the 1980s) express the involvement of some librarians in greater social movements, but information about the social justice activities of library workers centers on intra-institutional action.

\section{Outreach to the Underserved}

First, we will examine the increase of outreach in U.S. librarianship in the 1960s and '70s. This idea is significant because it reflects activism as it manifested in institutional awarenesses of poverty and "underserved" communities. Created in 1956 (and later expanded), the Library Services and Construction Act provided federal aid for public libraries. An amendment in 1970 called for an "emphasis on service to the disadvantaged"; public libraries used LSCA grants "to initiate outreach projects to poor communities, to bilingual constituencies, to Native Americans, to elderly and handicapped people, and to prisoners and mental patients also specified in the act" (Bundy and Stielow 1987, 7). Similarly, the 1965 Higher Education Act funded a fellowship and programs whose focus was on "minority/disadvantaged projects" (Bundy and Stielow 1987, 7).

The emphasis on a "war on poverty" in American political discourse led to the development of community action programs in accordance with the Economic Opportunity Act of 1964. The idea of "maximum feasible participation" of affected citizens-i.e. the poor themselves - was supposed to be the goal of these programs; however, the profession as a whole did not embrace new philosophies. Libraries failed to operate by anything approaching even the tepid spirit of this concept, largely avoiding incorporating the direct input of "the disadvantaged." According to Major Owens, "[i]nstead of maximum participation, there was maximum patronizing. People who seek the power of decision-making usually take a long-term view and press for the absorption of basic change by the institution. Most library administrators with LSCA and OEO [Office of Equal Opportunity] grants to serve the disadvantaged preferred a showcase approach with the grant activity carried as an appendage that could later be easily dropped" (Owens 1987, 75). At least one librarian noted at the time that "[t]he very choice of the term ['disadvantaged'] suggests a lack of the basic human empathy for which social responsibilitarians have called" (Raber 2007, 678). "Disadvantaged" was often coded as "urban black"- generally an "other" as far as white, middle-class librarianship was concerned. The gaps in class and life experience between most librarians and the populations they were trying to reach with these initiatives seemed to perpetuate a mistrust and discourage connection, and "real people were given a role to play as tokens in someone else's discursive formation" (Raber 2007, 678). 
Among a more conservative segment of the profession, there was a perception that "citizen participation [was] a radical incursion"; during the 1969 ALA conference in Atlantic City, conference organizers even alerted the National Guard to the possible threat of "people power" (Owens 1987, 79). Meanwhile, the seeds were being planted among socially conscious librarians for the eventual flowering of task forces under the auspices of the Round Table on Social Responsibilities in Libraries (RTSRL; this was the predecessor of the current-day Social Responsibilities Round Table, or SRRT). These task forces promoted materials by and for ethnic minorities, women, gays and lesbians, and other non-mainstream groups as "RTSRL's general goal-to make libraries more relevant to the public-provided the impetus for other task forces to address issues of access" (Samek 2001, 92).

As Bundy and Stielow conclude, "[t]he significance of the public library poverty programs of the Sixties was not the immediate programs; rather, it was that they promoted recognition that an institution traditionally catering to dominant cultural interests and serving largely ephemeral interests could make important social contributions" (Bundy and Stielow 1987, 10). The librarian Zoia Horn, remembered in part for her stay in jail for refusing to testify before a grand jury, discussed the growth of outreach and increased articulation of "social responsibilities" in librarianship of the 1960s and '70s: "I think it is fair to say that many librarians are indeed, socially responsible. They have extended library services to jails, to home-bound, and into rural areas; they have, indeed, established other language collections, created Information \& Referral Services, hired more minority librarians, and have done all of the above, with developed sensitivity to the many racial and ethnic groups in our society. That social responsibility must now be harnessed to the formation of local coalitions with other groups for the preservation of the lifeblood of democracy, the free and equal access to information, the right to know" (Peattie 1989, 370).

The "information and referral" (I\&R) concept was born in the late 1960s and was put into practice beginning in 1970. I\&R involved collecting data on community services and making these files available to the public. While its benefits initially included "increased contact with community agencies and the development of a more diverse clientele" (Durrance 1984, 167), I\&R was subject to questions about the degree to which these services altered the mission of libraries to that of social work - a debate that continues to this day, particularly in public librarianship. Community networks or community information systems are the next step in I\&R services. (The "ready reference kits" that RR members carried during the 2004 RNC were arguably portable I\&R centers.) Poe argues that too often reference librarians give sole credit to the books and electronic tools they use to answer questions, effacing their own part in the process. Rather, they should make clear to patrons their significant role in selecting resources and resolving information needs and "promote themselves as the best source of information" (Poe 2006, 37).

Community information programs of the early 1970 s attempted to put into practice the "Information Is Power" idea, but it was soon left to educational programs to carry out the realization (Bundy 1987, 91). Special institutes involving fieldwork and "outside 
expertise" were developed in library schools in the early 1970s, but since they were "[t]he result apparently of an individual faculty member's interest rather than a school commitment, institutes were short-lived educational efforts" (Bundy 1987, 85). Today, this concept lives on in places like the Urban Library Program in Minneapolis/St. Paul, Minnesota, but this is a paraprofessional program whose target participants are students from diverse backgrounds "who had never really considered a library career" (Willms and Wagner 2008, 30).

Apart from an explicit governmental emphasis on poverty eradication, library workers who are themselves members of groups affected by sub par or nonexistent library services were in many cases the fighters for improvements in the profession. According to Roberto P. Haro, "The Hispanic librarians of the 1960s were for the most part activists and pioneers who took considerable risks with their professional careers to lobby for improvements in library services to their respective communities" (Haro 1987, 150). James C. Welbourne, Jr.- - the leader of the Congress for Change, an initiative of library school students that shook up ALA in 1969-described the problems in black communities resulting from a culturally "white" structure of dissemination of information. $\mathrm{He}$ argued that self-determination via the resolution of information needs "could be aided significantly by a black information specialist" (Welbourne 1972, 57). However, "[o]ccupying a black skin" would not be enough to be a vital information specialist in the powerless, data-deprived "ghetto" areas where the seeds of black liberation lie: "They must know, and qualify for, membership in the evasive ghetto communication network'the vine.' They must be legitimate enough in the eyes of the black community to receive as many information 'tips' as they pass out-in short, they must be ghetto communication hustlers" (Welbourne 1972, 58-9).

The African American E.J. Josey, who worked with the Savannah branch of the NAACP and has held several leadership positions (including president) in ALA, was one of the first voices advocating desegregation and equal rights in librarianship. During a membership meeting at the 1964 ALA conference, he made the point that some state library associations had withdrawn from ALA rather than allow black librarians to participate in meetings. "From that moment on, ALA membership meetings would never be the same. The auditorium came to life," said Arthur Curley (Raber 2007, 677). Theneditor of Library Journal Eric Moon thought that "the Black issue" was what kicked off social awareness in librarianship in general and ALA in particular. "In fact it was the seed from which a lot of other things grew, the seed for the whole beginning of the social responsibility movement in ALA. The growth of the Social Responsibilities Round Table, in particular, the Gay Liberation movement, the women's movement. They all in some way could be said to have emerged from that initial impetus" (Moon and Stielow 1987, 105).

\section{Alternative Libraries and Reference Services}

Alternative libraries and reference services can be considered as a subcategory of outreach to the underserved. As Chris Dodge, former Utne Reader "Street Librarian" columnist, explains: "I think of my library as being wherever I am-it's not just a building 
full of shelves, but a living concept, a verb. A library can be about freely and extemporaneously providing connections, sometimes on a proactive basis" (Dodge 2003, 130).

The Bay Area Reference Center (BARC)—whose most famous employee was the coeditor of the seminal Revolting Librarians compilation, Celeste West-was a division of San Francisco Public Library that was open from 1967 to 1981, providing reference services to rural patrons, researchers, and other library systems. The BARC workers were forward-thinking, and the work of the center was technologically advanced. (Their publication Synergy is discussed below.)

Some academic libraries tried to develop space for underground materials. Roger C. Palmer attempted an Alternative Research Center at the State University of New York at Buffalo, contacting "Movement organizations" in preparation (Peattie 1989, 67), and Elliott Shore administered an "Alternative Acquisitions Project" at Temple University (Peattie 1989, 223ff). In the nonprofit field, the Data Center, originally affiliated with the North American Congress on Latin America (NACLA) and still thriving in Oakland, CA, is a socially responsible library for "investigative reporters, environmentalists, activists of all kinds, and just ordinary people concerned about being powerless in this complex society" (Peattie 1989, 364).

One interesting initiative that illustrates the tension and disconnects between librarians, ALA and other library associations, and activists is the Freedom Libraries of the mid1960s. During the Mississippi Freedom Summer Project in 1964, the main goal was registering African American voters, but other important components were the development of freedom schools and community centers, which included libraries. The Congress of Racial Equality (CORE) instituted a Books for Mississippi Project (later known as the Southern Education Project) in which donations were solicited from bookstores, churches, publishers, organizations, and individuals. The resulting Freedom Libraries "served civil rights goals in at least two ways: (1) by delivering books to the people who had no other access to them, and (2) by instilling an appreciation of information in people who then demanded service at their local public libraries" (Davis and Malone 1998, 121). Indeed, one of the hopes was that people who were exposed to the resources of these libraries would sit in at their own public libraries. This eventually did happen in Hattiesburg at the end of the summer and was the basis of the 1970 Supreme Court case Adickes vs. S.H. Kregs \& Co.

Virginia Steele, a library school graduate from Berkeley, applied to work at one of the community libraries and was "apparently...the only trained librarian who volunteered for the Freedom Summer Project" (Davis and Malone 1998, 114). Other volunteers were college students, teachers, and general members of the public. By the end of the summer of 1964, there were an estimated 25 libraries in approximately 45 project sites. In the spring of 1965, ALA-affiliated librarians formed the Friends of Freedom Libraries, and Miriam Braverman of Brooklyn (NY) Public Library was sent to investigate their operations. Braverman's final report ended: "The Freedom Libraries, therefore, play a role in making available to the local Negro population books they cannot get anywhere 
else. Until the social system of Mississippi becomes less repressive for the Negro, the Freedom Libraries will continue to be needed" (Davis and Malone 1998, 121). Some Mississippi library leaders were quietly supportive, but most "tended to ignore the inequities of service and the efforts of the Freedom Libraries" (Davis and Malone 1998, 120).

Individual librarians have long taken their expertise out into the world. Elizabeth Katz's piece in the original Revolting Librarians details the alternative information sources of the early 1970s, from "free libraries" to the Haight-Ashbury Switchboard (which lasted until 1986). In more recent times, Jessamyn West of Librarian.net has done reference work at the Burning Man festival (West 2002) and the 1999 WTO protests in Seattle. Chuck Munson of Infoshop.org has volunteered at the information desks of convergence centers during large demonstrations. In attempting to explain the concept of "anarchist librarians" to the rest of the profession, Munson writes: "You'll find anarchist librarians involved with infoshops, the local Independent Media Center, a special archive, or publishing a zine. Anarchist librarians... live their beliefs and are engaged in long-term struggles for social change. This means that an anarchist librarian who is concerned with media concentration and the stranglehold of intellectual property wouldn't just protest, but would go out and organize alternatives" (Munson 2003, 149).

A legitimate question is whether these varieties of volunteer-based assistance (including that which is provided under the auspices of Radical Reference) help excuse the inadequacies of public libraries, setting up a separate tier of services for those who are "in the know." One "revolting librarian" of the early 1970s alluded to this concern. In a piece about an ad-hoc library that she and another librarian-both members of the New Jersey Social Responsibilities Group—had set up at a weekly seasonal store for migrant workers, Jana Varlejs wrote: "The significance of [the migrant project] lies in the fact that it had to be carried out by a few dedicated people on their own time and largely with their own money, because the service was not being offered by the libraries that should have as a matter of course offered it. The nitty-gritty question to be faced here is: are we really being socially responsible librarians by continuing to provide a stop-gap service to the migrants on our own, or should we seek ways to force the issue of library service to migrants into the consciousness of the people who are in a position to really do something about it on a regular basis?" (Varlejs 1972, 67).

\section{The Alternative Press}

The other major type of collaborative library activism that has been documented is within the alternative press, both in terms of direct librarian involvement with the world of small presses and in alternative library publishing.

Noel Peattie and Toni Samek have analyzed intellectual freedom and social responsibilities in the context of the underground (or alternative) press of the 1960s. Peattie says that there were some connections between individual librarians and creators of alternative media, but not many: "In general, the plight of the underground press and of dissident organizations was ignored by librarians" (Peattie 1987, 47). 
Samek identifies four obstacles to librarians' embracing the alternative press: "as a concept intellectual freedom was not historically wedded to librarianship"; "censorship was a long-standing characteristic of library practice"; ALA's stance on neutrality as expressed in the Library Bill of Rights and elsewhere conflicted with the concept of social responsibility; and tension was generated when some librarians "denounced the legacy of bias in materials selection and forced the profession to reassess its responsibility to society and reconcile the weight of the status quo with the demands of social dissent" (Samek 2001, 38-9).

However, those who wished to promote non-mainstream materials saw a wider benefit to their communities: "Librarians who advocated social responsibility used the issue of the alternative press to redress a perceived imbalance in library collections, to provide enhanced information services to a broader public, to make the library more relevant to a changing society, and to show that long-standing library practices put the library profession in conflict with its own Library Bill of Rights" (Samek 2001, 46). In other words, rather than focusing on a narrow group of producers of underground literature, an awareness of alternative materials fosters a larger and more satisfied patron base and improves all library services.

The first people to see the potential of organizing and indexing underground writing were in fact not librarians. The organization now known as the Alternative Press Center (currently operating in Chicago) was begun in 1969 by students at Carleton College in Minnesota. That year, Carleton held a conference called "Vocations for Social Change" that inspired some students, led by Rod Stilger, and faculty to "creat[e] an index to the publications which amplified the cry for social change and social justice" (Peattie 1989, 408). The resulting project was named the Radical Research Center (RRC), and the Alternative Press Index was their creation. Although there were connections between the RRC and ALA, as well as dependence upon libraries for subscriptions to the Index, Stilger "was reluctant to be too closely linked to librarianship. He pointed out that RRC was not about doing librarians' work for them, but was motivated by its political agenda ....'Nothing against librarians, mind you, but essentially we're doing this for the sake of the movement, rather than for the sake of intellectual scholarship'" (Samek 2001, 24). Peggy D'Adamo got involved in 1974 as a recent graduate of the University of Maryland's library school, and Jackie Eubanks was among the volunteer indexers, but nearly all of the center's volunteers and collective members came from outside librarianship. (Eubanks even expressed "embarrassment" that the Index had been developed outside of ALA [Samek 2003, Intellectual].)

There is a mention of extracurricular documentation of the alternative press in the 1971 Report to the SRRT Membership and the Committee on Organization, submitted by Jackie Eubanks, Patricia Schuman, and David Weill. It stated that among the RTSRL activities was the provision of programs and services outside ALA, and "[o]ver 20 librarians...were clipping and copying news items that related to the defense in trials involving political repression" (Samek 2001, 107). A librarian named Joan Marshall organized a 1971 preconference workshop before the annual ALA conference to encourage librarians to volunteer to index the underground press. "We're librarians, 
we're indexers, we're needed!" she said in an announcement for the workshop (Samek 2001, 109).

One public expression of the alternative press was the New York Book Fair, which ran from 1974 to 1987. "Many literary people were involved, and many movement groups" (Peattie 1989, 139), and librarian Jackie Eubanks was among the driving forces. The 1974 ALA annual conference was held in New York at the same time as the New York Book Fair. Although "literary types and movement group workers" were in force at the Book Fair, "few ALA librarians bothered to attend." There were even "rumors that discussion at an ALA Exhibits Round Table meeting had turned to putting the New York Book Fair out of business" (Samek 2001, 137). Sandy Berman thought that the hostile reaction to alternative library literature by the establishment of the profession was "precisely because the literature they produced tightened connections between the alternative library movement and other movement groups and had the potential to make libraries 'more like the social catalysts they should be'" (Samek 2001, 135).

In terms of librarian-created alternative press, Sipapu, edited by UC Davis librarian Noel Peattie, and Synergy, the newsletter of the Bay Area Reference Center, were the most prominent representatives of the small pool of such publications in the previous generation. Peattie mostly filled issues of Sipapu with interviews by "non-librarians who were busy writing or publishing in the Third Word, counter-culture and free press." (He added, "While I still hope to hear from librarians, the 'tunnel between two worlds' at present carries voices from the non-library end only" [Peattie 1972, 134].)

Synergy ran from 1967 to 1973 and by 1968 "had hit its stride, with each issue featuring a theme of current interest: Bonnie and Clyde, astrology, art, poetry, the family, gay liberation, switchboards, the occult, women's liberation, the First Americans, Utopias and communes, etc. Synergy was radical, in both the sixties' and the eighties' senses of the word. It gave unflinching attention to any subject, regardless of controversy" (Roberts 1990). Celeste West remembered: "We realized we should publish, for libraryland at large, the precious resources we were finding on grassroots social, cultural and political stirrings. So we founded a 'zine, Synergy, to run news and source material on such phenomena as the Black Panther movement, communes, student strikes, prison reform, etc....Topics formerly dubbed underground, unworthy, and discreditable by the prudish and status quo were not only appearing in polite company, but were being clamored for by patrons ... Synergy offered a narrative by, for, and about the informationally marginalized" (West 2003, 9).

Within the profession, the Alternative Media Task Force (AMTF) is a subgroup of the Social Responsibilities Round Table of ALA that has existed, under different names, since 1970. The AMTF highlights independent publishers at the "Free Speech Buffet" at each annual ALA conference and promotes the alternative press to librarians. On the publishing side, the Committee of Small Magazine Editors and Publishers (COSMEP), which existed from 1968 through 1996, had strong connections to the library world and counted Jackie Eubanks and Noel Peattie as members. COSMEP held annual conferences that included panels on such topics as "what libraries could do for small 
presses, and vice versa" (Peattie 1989, 132) and "the ways by which small publishers can attract the favorable attention of academic librarians" (Peattie 1989, 271).

Current publications include Progressive Librarian, the journal of the Progressive Librarians Guild. PL began in 1990 and continues to publish scholarly articles on issues of interest to socially responsible library workers. Counterpoise, now a project of the Civic Media Center and Library in Gainesville, FL, is a journal and review source focused on the alternative press. In the online world, there are blogs like Canada's group effort librarianactivist.org and Jessamyn West's librarian.net that cover librarianship from a Left perspective. A much fuller list of alternative library literature past and present is included in Toni Samek's Library Juice article (Samek 2003, Intellectual).

Noel Peattie ended an essay written early in Sipapu 's life with the following inspiration to those in the library world who were contemplating editing journals of their own: "Your words may be read by many people outside librarianship, and you will find a tunnel out of that world into another. Perhaps if more librarians got to be known outside the field, it would be better for them as well as the profession. We are not respected, we say; perhaps this is because we talk mostly to each other. Who knows? The tunnel between two worlds may actually lead to the upper air" (Peattie 1972, 136).

\section{Coalitions and Community Connections}

A survey of progressive library history would not be complete without looking at the emphasis on coalition-building and community connections-a concept that drives RR-from the 1960s through today.

Sometimes simple interpersonal chemistry effected major change in the profession. Activist Barbara Gittings, a library user who used to search for unbiased materials on homosexuality in bookstores and libraries, heard that there was a new gay task force in ALA and approached the association. "The group seemed to be my natural home in the gay rights movement. I just found that librarians have a good spirit and a good sense of fun, and all you need to do is tap it a little bit and they can really let loose-better than most other professional groups," she later explained (Kniffel 1999, 74). Coalitionbuilding was also established as a priority for library institutions. Major Owens, who would later become a long-serving member of the House of Representatives from Brooklyn, NY, concluded that librarians need to form coalitions and alliances with other groups and "the massive number of individuals who are not already organized but who need our assistance" (Owens 1987, 81). The 1987 collection Libraries, Coalitions, \& the Public Good is entirely about the importance of coalition-building for economic selfinterest (the context of the Reagan era of privatization is sharp and clear in these essays) as well as other reasons. Joan C. Durrance's 1984 book, Armed for Action: Library Response to Citizen Information Needs, is a rich resource on the theory and practice of library services to organized citizen groups. 
Kathleen de la Peña McCook's A Place at the Table: Participating in Community Building is a more recent investigation of the relationships between library workers and their patron bases, including how the provision of reference materials is a way for librarians to further integrate themselves into a community. In a list of sample scenarios in which librarians use their expertise to assist in a community effort or issue, she includes the following: "Example: Broad areas without common concerns may not coalesce around an issue. A neighborhood wishing to preserve its main street appearance is unlikely to gain funding support or interest from nearby deed-restricted gated developments. Librarian's role: Attend community meeting. Provide maps of area and local history files" (McCook 2000, 46). Under the heading "The Library Can Make a Difference," she asserts: "All librarians are firm in their assessment of the role of the library in the community. By putting a face to the library at community meetings and events, these librarians feel they can connect to residents in ways that are meaningful for them. These librarians express optimism in the library as a place open to all and as a public service that can be innovative in response to people's real needs" (McCook 2000, $69)$.

There are many examples of librarians providing outreach and tailoring programming to their particular communities, of course-it is part of the regular work of most public librarians. Freeman and Hovde's Libraries to the People: Histories of Outreach (2003) is one source, containing essays covering library outreach to rural, tribal, and poor urban populations and the incorporation of innovative formats for programming, such as radio broadcasts. But when it comes to reaching activists and independent journalists who may have been turned off by a lack of relevant materials and services in their local libraries, Patricia Schuman's 1987 observation is still true: "Part of the problem is simply that most activist groups do not consider libraries as strategic access points for filling information needs. This attitude is recurrent and circular" (Schuman 1987, 130).

Now with the Internet and Web readily available to most, the influence of libraries-and, by extension, librarians-is even more tenuous for social justice activists. However, "[t]here is hardly a group - whether it represents the interests of educational institutions, environmentalists, civil rights organizations, or cultural or social organizations-that isn't deeply dependent upon access to information. We, as potential partners in such coalitions, bring to that alliance something extremely important to these members. We have an information specialty" (Curley 1987, 40). James Welbourne, Jr., spoke to the real-world effects of the resolution of information needs: "As a social dynamic in the black community, information is one of the most effective tools for organizing .... Information about health and welfare rights, about drug traffic and the political basis for its revenue, about organized crime and police complicity, about food co-ops, subsidized housing and other alternatives to the daily exploitation ghetto residents experience, could turn ghetto apathy into organized aggressiveness for control of basic community institutions and the right of self-determination" (Welbourne 1972, 52).

Sandy Berman's exhortation in the original Revolting Librarians collection is compelling because unlike the rest of the authors, he seemed to be writing not only for his fellow library workers but also for the radical (and presumably dissatisfied) would-be library 
users. He told the latter group they should be "putting the pressure on" librarians who would not make room in their collections for non-mainstream materials (Berman 1972, 55) and made the following important point:

[T] he pressure for change-if it's to be effective-needs to come from two directions: not only from inside the traditionally straight-laced, stuffed-shirted, status-quo-hugging profession, but also from outside, from the liberationists and undergrounders themselves, from angry feminists and alienated students, warring Indians and unshackled Blacks, from proud Chicanos and no-longer-docile Asian-Americans, from boss-burdened workers and impatient peaceniks. It's not merely our right to enjoy easy access to the books, pamphlets, films, tapes, discs, and mags we want, but equally a necessity that the mass of committed and largely uninformed citizens have access to sources that authentically explain what we're all about, that genuinely convey our vision of the 'alternative society.' If what Middle Amerika knows about the Black Panthers, as an example, derives solely from Time and tv, they'll never understand the BPs, nor all the fuss about 'persecution' and 'genocide.' The Movement, in short, if it's ever to shuck its insularity and really get its message to the Amerikan public, must be made more accessible. Libraries are one route. (Berman 1972, 52-3; emphasis in original)

\section{Organizing Structures}

Finally, a hallmark of RR that shows up in some of the literature is an openness of organizing structure. A sentiment behind which many in RR could unite was expressed by one of the members of 1969's Congress for Change. This student said during a planning meeting, "I see the 'social responsibility roundtables' becoming another establishment, another bureaucracy. A group like this, structured or nonstructured, which does not represent an establishment and does not wish to become one (with the concept of making the library once again relevant)" (Nelson 1987, 125; emphasis in original). Almost 30 years later, Mark Rosenzweig, an active participant in both SRRT and PLG, wrote: "Outside of Librarydom's official national organization, PLG leads an elusive, but perhaps equally important, existence as a program and an identity for librarians all over the country who are NOT involved in ALA, allowing us to feel that we are part of a community of radical librarians, that we are not alone, that we are linked through each other's individual activities to each other and to the various social movements and struggles" (Rosenzweig 1997).

In a more broadly radical statement, Jackie Eubanks once said: "Communications, in my mind, are the vanguard of any system. Under our present capitalist system, our libraries are among the very few socialist institutions that serve the people; they are, however, very hierarchical and rigid. As we progress, in order to preserve the freedom necessary to work in a socialist system, libraries and communications in general will have to be committed to anarchism, and libraries will have to be loosened up a lot more" (Peattie 1989, 138-9). This desire for flexible, fluid collegiality among librarians with shared values continues to be felt, and $R R$ is the most recent manifestation of it.

\section{Social Responsibilities in Other Professions}


The librarian's image is a rather tired object of discussion. However, the way we are perceived by the general public - not to mention activists-speaks to more grave concerns than simply whether or not librarians can be stylish and hip. Frederick Stielow, writing in the mid-'80s, said: "Rather than theory, the field took the easy road of concentrating on a practical and seemingly non-controversial trade school approach. Similarly, librarianship appeared increasingly comfortable in resigning from its stewardship as an 'arsenal of democracy.' Instead of service and enlightenment for all elements of society, it all but embraced passivity and de facto middle-class limits. Thus librarians never achieved the status of progressive professionals, or even retained their earlier stereotype as scholarly bibliophiles, in the public's mind-rather, they were saddled with the eviscerated visage of the stern library hostess" (Stielow 1987, 176). In more recent years, a spate of articles in the mainstream press following the passage of the PATRIOT Act emphasized the incongruity of librarians' taking a vocal stand against government repression: "Of all the common stereotypes of various professions-the sleazy lawyer, the absentminded professor, the kindly grocer-few are more potent than that of the mousy, officious librarian. That image is so ingrained that it's nearly impossible to think of librarians as agitators, radicals, or troublemakers" (Hayes 2003).

But many within the profession are frustrated with this assessment. A recent essay by a library director bemoaned librarians' lack of status, respect, and energy and urged us to become "knowledge provocateurs" (Baldwin 2006). Peattie looked at the accepted wisdom of the 1990s and concluded: "Yet while we ally ourselves with business because 'that's where the money is' (as Willie Sutton said about banks), our natural allies are not corporate entrepreneurs but people doing work parallel to ours: teachers and social workers, men and women in the health and helping professions, consumer advocates and civil rights organizers, scholars and artists, scientists and environmentalists" (Peattie 1996, 40).

Within the field of librarianship, radical archives such as the Labadie Collection explicitly collect and protect materials related to activist and other non-mainstream communities. As in librarianship as a whole, archivists' work until the mid-20th century reflected the values of the dominant culture. One archivist assesses the mid-century shift: "In the 1960s, however, archivists began to react to an emerging generation of historians who sought to write what was called the new social history. This approach broadened the story of America's past by including groups previously excluded in the Great White Man view of events-women, blacks, Native Americans, religious minorities, immigrants, the working class, and gay men and lesbians .... This new activist concept was framed generally by the term documentary strategy, and it marked an important step by archivists toward taking their role as the definers of history more seriously. The acquisition of archival material became more theoretical and thoughtful" (Britton et al 2006, 218-9).

Other professions find an easier relationship between their general work and services to targeted activist communities. Some academic fields are more readily associated with social justice work. Unlike librarianship, social work, for example, began with a more radical philosophy. "[T]oday archival and oral history evidence, fragmented as it is, does 
confirm that the early psychoanalytic movement was built around a progressive political core, closely allied to the cultural context of central Europe from 1918 to $1933 \ldots$

Psychoanalysis was as progressive a socio-cultural movement as the art, music and architecture of the 1920s" (Danto 2009, 74-5). In the view of one sociologist, one of the two major paths of recruitment to the profession is "the path of social activism. Many, perhaps most of us, became interested in sociology because we belonged to social movements or had social commitments. We wanted to do something to change society, help people, fight injustice, and elevate the oppressed" (Collins 1998, 3-4). This same article identifies as "disciplines that are even more thoroughly politicized than sociology... relatives of sociology, such as ethnic studies, black studies, and women's studies, which were created as hybrids between academic departments and activist movements" (Collins 1998, 4).

The field of medicine holds a variety of ways for professionals to combine their progressive values with their expertise. Jim Withers, M.D., is known as the pioneer of "street medicine." In 1992, he first went out after hours to provide medical assistance to the homeless of Pittsburgh. The following year, he founded a nonprofit called Operation Safety Net, which now boasts "teams of volunteers made up of paramedics, primary care physicians, registered nurses, podiatrists, dentists and the formerly homeless, as well as medical students and residents serving clerkships" (Hunt 2002, 20). There are now several groups of physicians around the country that similarly use their expertise to help homeless and other marginalized people.

In far more politicized settings, street medics take their training to demonstrations. These workers represent a "collection of doctors, EMTs, and ordinary civilians who have taken it upon themselves to offer medical care for crowds at progressive rallies and street actions" (Blanding 2004, 26). They "hold up action medicine as a more egalitarian counter-model to a mainstream health-care system that's becoming increasingly profitdriven .... We're really talking about people-powered medicine,"' one medic puts it (Blanding 2004, 26). A recent event that spurred trained activists and medical professionals to come together was Hurricane Katrina. Common Ground was started by both New Orleans residents and others who traveled to the city to help; while medical clinics were a major part of the project, the first workers were non-professional medics. Eventually, nurses and physicians filtered in as word spread (Shorrock 2006).

Anyone involved in activist struggles is familiar with the value of legal expertise. The National Lawyers Guild was founded in 1937 "as an alternative to the then-segregated ABA [American Bar Association]" (Barnes 1995, 23). Members—who are lawyers, law students, and other legal workers-conduct "Know Your Rights" trainings and act as legal observers (usually wearing fluorescent green caps) during protests and rallies. "Though most legal observers acknowledge that their own politics tend to align them closer to the activists than to police, they pride themselves on their neutrality during events" (Nanos 2004, 32). Other independent groups, such as the Bay Area's Midnight Special Law Collective, offer trainings and plain language legal materials specifically for progressive activists. 
Journalism is, of course, a field with which RR allies itself. The work of socially responsible media makers is, like that of RR, based in fact but aiming for a constituency or audience with shared progressive values. The so-called "alternative" or "underground" press in the U.S. had its origins in the middle of the 20th century, and the media landscape continues to offer mainstream as well as progressive and radical publications and websites. The growing accessibility of journalistic content online-both to read it and to create it-adds to the ability for a multiplicity of voices and biases to flourish on the Web.

Dan Berger puts the conviction of activist journalists into words when he writes that "the problem with the media isn't just its for-profit status or the saturation of advertising .... Rather, the problem is one of power-who has access to use, create, and disseminate media; who is given a voice; who is disempowered; what communities are specifically targeted" (Berger 2004, 39). In recent years, people of color have been leading the drive for media justice, not mere reform, in which "race, class, and gender conscious frameworks ... advance new visions for media content and structure" (Themba-Nixon $2003,3)$. While debates about the role of biased reporting and non-credentialed media makers show no signs of quieting down, both in layperson and professional journalism circles, there will always be journalists using their political values to inform their work.

\section{Response to RR from Activist Community Partners and Users}

In the context of the above movements, $R R$ represents a traditional and technological mashup of activism, outreach, and teaching for a new socially conscious user. RR has had the opportunity to work with many individuals since the 2004 RNC, both online and in person. Often people do not give clues in their questions to determine how they heard about the group, who they are, or how they plan to use the information they will get, but excerpts from the website show that RR is reaching its target patron base:

- "I do research for Mumia Abu-Jamal's books and radio commentaries ..." (http://radicalreference.info/node/1203)

- "I'm working with a writer on an article about the reforms to the Rockefeller Drug Laws that were recently signed into law." (http://radicalreference.info/node/559)

- "I'm working on an article on the radical right on college campuses for an upcoming indy article." (http://radicalreference.info/node/508)

- "I'm writing on propaganda preparation of the Iraq war by the INC/NeoCon complex." (http://radicalreference.info/node/91)

- "I'm looking for historic images of NYC for a documentary that I'm working on for my group, Heads On Fire." (http://radicalreference.info/node/390)

- "[M]y video collective is making a documentary on military recruitment and possibly on the draft ... (http://radicalreference.info/node/30)

In a few cases, members actually know questioners, strengthening the real-life bonds between library workers and activists. For example, Victoria Law, a writer in New York City, has submitted several questions over the years, asking about media coverage of prisoners' hunger strikes, statistics on battered women, and legal cases on prisoner 
abuse. Her work was for a book titled Resistance Behind Bars, currently in publication at PM Press, and she said of her research assistance, in an email dated January 20, 2009: "The librarians that I have worked with through Rad Ref have gone above and beyond what I have come to think of as typical desk service at my local libraries .... Most of the information and documentation that I was seeking was relatively obscure and unavailable to those who are not in a university setting. The librarians associated with Rad Ref not only answered my questions and direct me to the sources that I needed, but explained how they arrived at their answers."

Most of the time, community members who find RR reach the site by hearsay, knowing little more than its name. Andalusia Knoll, a contributor to Pacifica Radio and a member of The Prometheus Radio Project described in an email dated December 17, 2008, how she "was on a very tight deadline and wrote Rad Ref looking for articles outlining the candidates positions on retroactively implementing the Sentencing Commissions change for eliminating disparities in Crack-Cocaine sentences. Within an hour Radical Reference [sent] useful links and articles that helped... complete the story and include[d] each candidates stance on crack/cocaine sentencing."

In some areas, RR members have sufficient numbers in a single city to form a local collective, which can then partner with non-librarian groups. In New York City, bonds have formed with the Grassroots Media Coalition (GMC), a community of progressive media organizations. RR has had a presence at the annual GMC conferences since 2005 and has been a partner in the coalition since 2007. Hilary Goldstein, a media maker who helps manage the GMC, had this to say about their partnership, in an email dated December 8, 2008:

In 2007, Radical Reference signed on as a partner organization of the NYC Grassroots Media Conference organizing committee. RadRef ... went far above and beyond this call of duty by organizing a number of workshops and becoming more regular participants in our general organizing meetings. ..This partnership wasn't the NYCGMC's first experience with Radical Reference. Rad Ref has participated in NYC Grassroots Media events since at least as early as 2005-giving workshops on how to organize online data, how to fact check and how to take advantage of free resources at local libraries. Their workshops provide a really crucial element to our programs ... I think that we're becoming a less informed society, despite having the tools at our fingertips. I think Radical Reference is working to provide solutions to this. In particular, their fact checking workshops have been incredibly popular at the NYC Grassroots Media Conferences. Learning how to rigorously fact check our own work whether it's in a video project, a blog post or a community news journal is necessary to build trust in alternative sources of information-and having the tools to investigate and question the information we are receiving is equally vital...Information is power-learning how to better access information to support our campaigns, our media, and our communities is critically important.

In 2009, RR members in Portland, OR, created a community lending library of the books and resources at Bitch Magazine, a respected feminist magazine based in that city. 
Editor Debbie Rasmussen stated in an email dated December 2, 2008 that RR "brought skills and expertise that none of us here at Bitch had-everything from where to place the lending library, to what kind of shelves we should build, to what categories we should have and where they should go, to how we should organize them in an online catalogue ... We were pretty lost until they arrived! ... It's brought new meaning to the work we do because we'll finally have a way of connecting more directly with the community here in Portland, on top of connecting with an amazing group."

\section{Outreach and Education}

$\mathrm{RR}$ members are participants in activist campaigns and otherwise integrally involved in the social justice communities with which they work. For example, the New York collective has been approached by the NYC Independent Media Center to provide research support for their newspaper, and it was called upon to catalog the collection of documents, videos, and periodicals archived by a local environmental group. An RR member in Boston helped coordinate the Iraq Veterans Against the War (IVAW) Winter Soldier campaign in 2008.

Carrying on the tradition of librarians' active involvement in the alternative press, $R R$ members have helped organize and conduct workshops at radical and anarchist book fairs. Recent RR collaborators and partners in the community include:

- The 2008 NYC Grassroots Media Conference, where RR was a coalition partner, helping plan and execute this annual event. Members conducted two workshops, "Radical Reference Presents: The 2008 Grassroots Media Election Guide" and "Alternative Voices on the Internet: Managing the News Online."

- The Women and Media Conference in 2008, at which "FACT-UP: Fact Check, Research and Thinking Critically like a Radical Librarian" introduced factchecking skills and research strategies to both storied reporters and novices.

- The NYC Anarchist Book Fairs, which RR members have helped plan. An RR workshop called "The Importance of Community Needs Assessment in Activist Work" was presented in 2008.

- The Mid Atlantic Radical Bookfair in 2007, where RR members, along with other information and library advocates, conducted a panel discussion on social equality and radical services as a form of activism.

- The US Social Forum of 2007, which saw an ambitious librarian effort led by members of RR and PLG. One goal was to collect materials from the forum itself to preserve and archive this social movement history. Another was to survey forum attendees on attitudes towards activism, libraries, and information-seeking. A third was to provide reference services in the forum's Media Justice Center, including conducting the workshop "Media Essentials: Research and FactChecking." 
The outreach and teaching that RR does in the community is advantageous to all involved. A full list of RR appearances is available at

http://radicalreference.info/rrpresentations.

\section{Conclusion}

Samek writes that "[p]rogressive library discourse is a site of contestation for various stakeholders in the dominant culture of the profession, because it challenges librarianship to reconceptualize the traditional ethic of intellectual freedom," both as workers and as citizens (Samek 2003, Pioneering, 138). It's not easy to unify the values of librarians (despite our reputation as members of a relatively liberal profession). (For example, something we can now agree is literally black and white-segregation-was contentious in librarianship into the '60s.) Today, as library workers wrestle with issues related to corporatism, privatization, de-professionalization, privacy, bias and media ownership, debates continue to take place in the journals and the blogosphere.

Throughout modern library history, there have been librarians who embraced social justice work and provided strong intellectual justification for their progressive values. It is important to dispute the notion of detached objectivity in information services and to make room for all levels of library activism both within professional associations and beyond in the larger sphere. The latter realm is where RR has chosen to devote its energies, forming partnerships that embrace the places where we share ideals, needs, and solutions. The challenges and excitement of collaborating with the greater activist world engage us as community members and invigorate us as librarians.

\section{Works Cited}

Baldwin, Michael. 2006. Librarians as knowledge provocateurs. Public Libraries 45, no. 2: 11-14.

Barnes, Patricia G. 1995. A lawyer group with a mission. ABA Journal81, no. 7: 23.

Berger, Dan. 2004. The problem of the media: U.S. communication politics in the 21 st century. Clamor 27: 39.

Berman, Sanford. 1972. Libraries to the people! In Revolting librarians, eds. Celeste West and Elizabeth Katz, 51-7. San Francisco: Booklegger Press.

Blanding, Michael. 2004. "MEDIC!" Peacework 31, no. 347: 26.

Britton, Diane F., Barbara Floyd, and Patricia A. Murphy. 2006. Overcoming another obstacle: Archiving a community's disabled history. Radical History Review 94: 211-227.

Bundy, Mary Lee. 1987. The social relevancy of library education: An accounting. In Activism in American librarianship, 1962-1973, eds. Mary Lee Bundy and Frederick J. Stielow, 83-97. New York: Greenwood Press. 
Bundy, Mary Lee with Frederick J. Stielow. 1987. Overview of an era. In Activism in American librarianship, 1962-1973, eds. Mary Lee Bundy and Frederick J. Stielow, 510. New York: Greenwood Press.

Collins, Randall. 1998. The sociological eye and its blinders. Contemporary Sociology 27, no. 1:2-7.

Curley, Arthur. 1987. Towards a broader definition of the public good. In Libraries, coalitions, \& the public good, ed. E.J. Josey, 34-42. New York: Neal-Schuman.

Danto, Elizabeth Ann. 2009. A new sort of 'Salvation Army': Historical perspectives on the confluence of psychoanalysis and social work. Clinical Social Work Journal 37: 6776.

Davis, Donald G. and Cheryl Knott Malone. 1998. Reading for liberation: the role of libraries in the 1964 Mississippi Freedom Project. In Untold stories: Civil rights, libraries, and Black librarianship, ed. John Mark Tucker, 110-25 . Champaign, IL: Publications Office, Graduate School of Library and Information Science.

Dodge, Chris. 2003. Libraries to the people, redux. In Revolting librarians redux: Radical librarians speak out, eds. Katia Roberto and Jessamyn West, 128-36. Jefferson, N.C.: McFarland.

Durrance, Joan C. 1984. Armed for action: Library response to citizen information needs. New York: Neal-Schuman.

Freeman, Robert S. and David M. Hovde. 2003. Libraries to the people: Histories of outreach. Jefferson, N.C.: McFarland.

Free Software Foundation. 2009. The free software definition. http://www.fsf.org/licensing/essays/free=sw.html (accessed September 9, 2009).

Haro, Roberto P. 1987. The development of library programs for Hispanics in America: 1962-1973. In Activism in American librarianship, 1962-1973, eds. Mary Lee Bundy and Frederick J. Stielow, 141-51. New York: Greenwood Press.

Hayes, Christopher. 2003. Librarians, liberals with backbone. The American Prospect February 19, http://www.prospect.org/cs/articles?article=shelf life (accessed February 12, 2009).

Hunt, Linda Boone. 2002. Mercy on the streets. Modern Physician 6, no. 12: 20.

Kniffel, L. 1999. Gay liberation: from task force to round table. American Libraries 30, no. $11: 74-6$. 
Lamb, Gregory M. 2009. Twitter's secret: The law of unintended consequences. Christian Science Monitor February 12, http://features.csmonitor.com/innovation/2009/02/12/twitter\%E2\%80\%99s-secret-thelaw-of-unintended-consequences/ (accessed March 1, 2009).

McCook, Kathleen de la Peña. 2000. A place at the table: Participating in community building. Chicago: American Library Association.

Moon, Eric with Frederick J. Stielow. 1987. The library press and Eric Moon: An interview. In Activism in American librarianship, 1962-1973, eds. Mary Lee Bundy and Frederick J. Stielow, 99-111. New York: Greenwood Press.

Munson, Chuck. 2003. What do radical librarians do? Or, which way to the black bloc? In Revolting librarians redux: Radical librarians speak out, eds. Katia Roberto and Jessamyn West, 148-53. Jefferson, N.C.: McFarland.

Nanos, Janelle. 2004. The watchers. The Village Voice 49, no. 32: 32.

Nelson, James A. 1987. The Congress for Change. In Activism in American librarianship, 1962-1973, eds. Mary Lee Bundy and Frederick J. Stielow, 123-33. New York: Greenwood Press.

Owens, Major R. 1987. The war on poverty and community outreach. In Activism in American librarianship, 1962-1973, eds. Mary Lee Bundy and Frederick J. Stielow, 7382. New York: Greenwood Press.

Peattie, Noel. 1972. Sipapu: A tunnel between two worlds. In Revolting librarians, eds. Celeste West and Elizabeth Katz, 133-6. San Francisco: Booklegger Press.

Peattie, Noel. 1987. Intellectual freedom activism in the sixties: The defense of a professional standard. In Activism in American librarianship, 1962-1973, eds. Mary Lee Bundand Frederick J. Stielow, 43-58. New York: Greenwood Press.

Peattie, Noel. 1989. A passage for dissent: The best of Sipapu, 1970-1988. Jefferson, N.C.: McFarland \& Co.

Peattie, Noel. 1996. On my mind: Reflections on the Sipapu years. American Libraries 27, no. 5: 39-40.

Poe, Jodi. 2006. Information and referral services: A brief history. The Southeastern Librarian 54, no. 1: 36-41.

Raber, Douglas. 2007. ACONDA and ANACONDA: Social change, Social responsibility, and librarianship. Library Trends 55, no. 3: 675-97. 
Roberts, Kay. 1990. BARC: A brief history of California's first statewide reference center. Wilson Library Bulletin 64: 32-5,

http://vnweb.hwwilsonweb.com/hww/jumpstart.jhtml?recid=0bc05f7a67b1790e93bc5aec 36f607ca30d1c2effe6c4c3eb572fb3cbccf20855680a35855d05629\&fmt=H (accessed January 22, 2009).

Rosenzweig, Mark. 1997. PLG - Why we keep on going. http://libr.org/plg/PLG-why.php (accessed February 15, 2009).

Samek, Toni. 2001. Intellectual freedom and social responsibility in American librarianship, 1967-1974. Jefferson, N.C.: McFarland.

Samek, Toni. 2003. Intellectual freedom within the profession: A look back at freedom of expression and the alternative library press. Library Juice 6.6 (March 14), http://www.libr.org/juice/issues/vol6/LJ 6.6.html (accessed February 12, 2009).

Samek, Toni. 2003. Pioneering progressive library discourse. In Revolting librarians redux: Radical librarians speak out, eds. Katia Roberto and Jessamyn West, 137-42. Jefferson, N.C.: McFarland \& Co.

Samek, Toni. 2004. Internet AND intention: An infrastructure for progressive librarianship. International Journal of Information Ethics 2 (November), http://container.zkm.de/ijie/ijie/no002/ijie 00223 samek.pdf (accessed March 2, 2009).

Schuman, Patricia. 1987. Libraries and coalition building. In Libraries, coalitions, \& the public good, ed. E.J. Josey, 127-33. New York: Neal-Schuman.

Shorrock, Tim. 2006. The street samaritans. Mother Jones 31, no. 2: 64-7.

Stielow, Frederick J. 1987. A pivotal era in the professionalization of librarianship: Historical speculations on the sixties. In Activism in American librarianship, 1962-1973, eds. Mary Lee Bundy and Frederick J. Stielow, 175-8. New York: Greenwood Press.

Themba-Nixon, Makani. 2003. Pleading our own cause: People of color are leading an effort to define media justice as a movement not for content-neutral reforms but a vision of racial justice. Colorlines 6, no. 4: 3.

Varlejs, Jana. 1972. Continuing it? In Revolting librarians, eds. Celeste West and Elizabeth Katz, 67-8. San Francisco: Booklegger Press.

Welbourne, Jr., James C. 1972. The information potential in the liberation of black people. In What black librarians are saying, ed. E.J. Josey, 50-9. Metuchen, N.J.: Scarecrow Press.

West, Celeste. 2003. Introduction to Revolting librarians redux: Radical librarians speak out, eds. Katia Roberto and Jessamyn West, 5-16. Jefferson, N.C.: McFarland. 
West, Jessamyn. 2002. On the fly reference. American Libraries 33, no. 5: 54-7.

Willms, Debbie and Mary M. Wagner. 2008. The urban library program: Building careers while reflecting cultures and communities. Public Libraries 47, no. 6: 27-34. 